\title{
STRATEGI TELKOM UNIVERSITY DALAM MENINGKATKAN KUALITAS PELAYANAN ASRAMA MAHASISWA
}

\author{
Berlian Primadani Satria Putri \\ Fakultas Komunikasi dan Bisnis, Telkom University \\ berlianprimadani@telkomuniversity.ac.id
}

\begin{abstract}
ABSTRAK
\end{abstract}
Perusahaan manapun sebagai sebuah lembaga bisnis yang walaupun tujuan utamanya adalah keuntungan atau "profit", namun dalam prosesnya mereka harus mengutamakan pelayanan yang diberikan, sehingga kepuasan pelanggan dapat tercapai. Kualitas menjadi penting ketika seorang konsumen memutuskan untuk membeli atau tidak membeli, menggunakan kembali, bahkan merekomendasikan produk atau jasa kepada orang-orang di sekelilingnya, karena kualitas inilah yang menjadi tendensi seseorang itu puas atau tidak puas terhadap produk atau jasa yang digunakannya. Sebagai lembaga penyedia program pendidikan yang ingin menjadi World Class University, Telkom University selalu berusaha dalam meningkatkan kualitas pelayanannya meliputi segala aspek sarana dan prasarana termasuk Asrama sebagai bentuk pelayanan kepada mahasiswanya. Metode penelitian ini adalah kualitatif deskriptif dengan melakukan wawancara kepada pihak management PT CSM (Citra Sukapura Megah), selaku pengelola dan penanggungjawab Asrama mahasiswa Telkom University. PT CSM telah berusaha untuk memberikan pelayanan-pelayanan yang terbaik didalam asrama mahasiswa Telkom University dimana dimensi strategi kualitas pelayanan yang meliputi aspek tangibles, emphaty, reliability, responsiveness, dan assurance telah dilakukan dengan baik dan terencana.

Kata kunci: Kualitas Pelayanan, Strategi, Asrama 


\section{Pendahuluan}

Kualitas merupakan ukuran bagi seseorang dalam membandingkan pengalaman faktualnya ketika menggunakan produk atau jasa dengan ekspektasi awalnya terhadap produk atau jasa tersebut berdasarkan kriteria-kriteria tertentu. Kualitas menjadi penting ketika seorang konsumen memutuskan untuk membeli atau tidak membeli, menggunakan kembali, bahkan merekomendasikan produk atau jasa kepada orang-orang di sekelilingnya, karena kualitas inilah yang menjadi tendensi seseorang itu puas atau tidak puas terhadap produk atau jasa yang digunakannya. Di setiap lini bisnis, kualitas pelayanan menjadi konsentrasi utama yang harus diperhatikan oleh para pemasar sebelum mengomunikasikan tingkat keunggulan bersaingnya dibandingkan kompetitor lainnya kepada calon konsumennya, karena disinilah image tentang kepuasan pelanggan akan dipertaruhkan. Secara definitif, kualitas pelayanan atau service quality dapat diartikan sebagai upaya pemenuhan kebutuhan dan keinginan konsumen serta ketepatan penyampaiannya dalam mengimbangi harapan konsumen [1]. Kualitas pelayanan dapat diketahui dengan cara membandingkan persepsi konsumen atas pelayanan yang secara faktual mereka peroleh dengan pelayanan yang sesungguhnya mereka harapkan terhadap atribut-atribut pelayanan yang ditawarkan suatu perusahaan. Jika jasa yang diterima atau dirasakan (perceived service) sesuai atau bahkan melebihi apa yang diharapkan, maka kualitas pelayanan akan dipersepsikan baik, berkualitas dan memuaskan,. Sebaliknya jika jasa yang diterima lebih rendah daripada yang diharapkan, maka kualitas pelayanan dipersepsikan buruk atau mengecewakan. Kekecewaan pelanggan ini yang nantinya akan berakibat pada timbulnya persepsi negative dalam masyarakat dan nantinya akan berdampak pada citra negatif perusahaan tersebut.

Telkom University merupakan salah satu institusi pendidikan tinggi yang berkomitmen dalam memperhatikan kualitas pelayanan meliputi segala aspek sarana dan prasarana yang akan meningkatkan standar mutu pendidikan untuk menunjang terwujudnya World Class University pada tahun 2018. Telkom Foundation yang menaungi 
Telkom University, kemudian menugaskan PT Citra Sukapura Megah (CSM) untuk bertanggung jawab atas segala bentuk pembangunan gedung dan perawatan fasilitasfasilitas termasuk untuk pengelolaan Asrama Mahasiswa.

PT CSM selalu berusaha memberikan pelayanan terbaik bagi penghuni asrama, tetapi pada kenyataannya masih terdapat berbagai keluhan mengenai ketidakpuasan penghuni terhadap kualitas pelayanan dan fasilitas yang diberikan. Hal ini merujuk pada penelitian yang dilakukan oleh Rico Anugrah Putra (2016) yang menyatakan bahwa kualitas pelayanan asrama Telkom University termasuk dalam kategori buruk sesuai dengan garis kontinum yaitu mendapat persentase skor total sebesar $60,43 \%$, yang kemudian dapat disimpulkan bahwa kualitas pelayanan yang telah dilakukan oleh asrama Telkom University masih perlu ditingkatkan lagi guna untuk menciptakan rasa kepuasan dari mahasiswa penghuni asrama. Dis isi lain kepuasan mahasiswa penghuni asrama Telkom University juga termasuk dalam kategori buruk, yang direpresentasikan pada garis kontinum dengan persentase skor total sebesar 54,19\%, dimana dapat diartikan bahwa responden dalam penelitian tersebut dinyatakan masih belum merasa puas terhadap pelayanan asrama Telkom University[2].

Banyaknya masalah dan keluhan mengenai kurangnya fasilitas asrama Telkom University juga dibuktikan dengan sebuah video di media sosial Youtube berjudul "Kurangnya Fasilitas Asrama" yang di upload pada tanggal 18 November 2015. Didalam video terdapat beberapa mahasiswa baru Telkom University angkatan 2015 yang diwawancarai mengenai keluhan-keluhan apa saja yang dirasakan selama mereka berada di asrama. Selain itu juga ada video berjudul “Aksi Mahasiswa Baru 2013 Memperjuangkan HAK Mereka di Asrama YPT" yang diupload pada tanggal 20 September 2013 dan telah ditonton sebanyak 5.374 kali dan muncul juga beberapa komentar negatif didalam video tersebut. Jika tidak segera ditangani, maka fakta-fakta tersebut akan menjadi masalah yang sangat serius yang akan membuat citra Telkom University menjadi negatif di mata 
masyarakat, khususnya bagi mahasiswa baru Telkom University yang setiap tahunnya akan menjadi penghuni baru di asrama mahasiswa.

Dengan fakta-fakta tersebut maka permasalahan ini layak diteliti untuk mengetahui bagaimana strategi Telkom University dalam meningkatkan kualitas pelayanan asrama mahasiswa, yang dalam hal ini PT CSM sebagai pengelolanya.

\section{Kajian Pustaka}

\section{Pengertian Jasa}

Pengertian jasa menurut kamus besar Bahasa Indonesia, "Jasa adalah menyediakan segala yang dibutuhkan orang lain" dalam hal ini konsumen. "An activity, benefit, or satisfaction offered for sale that is essentially intangible and does not result in the ownership of anything" [5].

Jasa merupakan sebuah kegiatan, manfaat atau kepuasan yang ditawarkan untuk dijual yang pada dasarnya tidak berwujud dan tidak mengakibatkan kepemilikan apapun. Jadi, jasa (service) adalah aktivitas atau manfaat yang ditawarkan oleh satu pihak kepada pihak lain yang pada dasarnya tanpa wujud dan tidak menghasilkan kepemilikan apapun. Produksinya mungkin terikat atau tidak pada produk fisik. Perusahaan jasa yang berhasil memfokuskan perhatiannya pada konsumen, mereka akan memahami rantai pelayanan yang dapat terhubung dengan kepuasan konsumen.

\section{Kualitas Pelayanan}

Kualitas adalah sesuatu yang diputuskan oleh pelanggan, artinya kualitas didasarkan pada pengalaman aktual pelanggan atau konsumen terhadap produk atau jasa yang diukur berdasarkan persyaratan-persyaratan tersebut[6]. Kualitas produk dan jasa didefinisikan sebagai keseluruhan gabungan karakteristik produk dan jasa yang dihasilkan dari pemasaran, rekayasa, produksi dan pemeliharaan yang membuat produk dan jasa tersebut dapat digunakan memenuhi harapan pelanggan atau konsumen. 
Definisi pelayanan adalah setiap tindakan atau kegiatan yang dapat ditawarkan oleh suatu pihak kepada pihak lain, yang pada dasarnya tidak berwujud dan tidak mengakibatkan kepemilikan apapun[5]. Produksinya dapat dikaitkan atau tidak dikaitkan pada satu produk fisik. Pelayanan merupakan perilaku produsen dalam rangka memenuhi kebutuhan dan keinginan konsumen demi tercapainya kepuasan pada konsumen itu sendiri.

Kualitas pelayanan adalah tingkat keunggulan yang diharapkan dan pengendalian atas tingkat keunggulan tersebut untuk memenuhi keinginan pelanggan[1]. Apabila jasa atau pelayanan yang diterima atau dirasakan (perceived service) sesuai dengan yang diharapkan, maka kualitas jasa atau pelayanan dipersepsikan baik dan memuaskan. Jika jasa atau pelayanan yang diterima melampaui harapan pelanggan, maka kualitas jasa atau pelayanan dipersepsikan sebagai kualitas yang ideal. Sebaliknya jika jasa atau pelayanan yang diterima lebih rendah daripada yang diharapkan, maka kualitas jasa atau pelayanan dipersepsikan buruk.

\section{Dimensi Kualitas Pelayanan}

Adapun lima dimensi pokok Service Quality (SERVQUAL) yang paling menentukan kualitas pelayanan adalah sebagai berikut ${ }^{[4]}$ :

\section{Tangibles (bukti fisik)}

Meliputi bukti fisik, perlengkapan, pegawai dan sarana komunikasi serta kendaraan operasional. Contoh: fasilitas reparasi, seragam karyawan, kelengkapan peralatan, dan ruang tunggu yang nyaman.

\section{Empathy (empati)}

Meliputi kemudahan dalam melakukan hubungan, komunikasi yang baik dan memahami kebutuhan konsumen. Contoh: seorang dokter mengenal pasiennya dengan baik, mengingat penyakit dan keluhan sebelumnya, bersikap sabar serta menjadi pendengar yang baik. 
3. Reliability (keandalan)

Merupakan kemampuan memberikan pelayanan yang dijanjikan dengan segera dan memuaskan. Contoh: dokter mampu mendiagnosis penyakit pasien dengan akurat.

4. Responsiveness (daya tanggap)

Merupakan sikap tanggap pegawai dalam memberikan pelayanan yang dibutuhkan dan dapat menyelesaikan dengan cepat. Contoh: sistem reservasi dan penanganan bagasi maskapai penerbangan yang cepat.

5. Assurance (jaminan)

Meliputi jaminan-jaminan yang dijanjikan sesuai dengan kenyataan, sifat dapat dipercaya yang dimiliki pegawai, bebas dari bahaya, risiko dan keraguraguan. Contoh: mekanik di bengkel yang berpengetahuan dan berpengalaman luas.

\section{Metode Penelitian}

Penelitian ini bertujuan untuk menggambarkan realita secara mendalam terkait datadata yang dikumpulkan. Metode kualitatif yang digunakan adalah kualitatif deskriptif. Kualitatif deskriptif merupakan penelitian dengan mengumpulkan data berupa kata-kata, gambar dan bukan angka-angka. Pertimbangan peneliti menggunakan metode kualitatif , yaitu untuk memahami fenomena yang sedang terjadi secara alamiah (natural) dalam keadaan-keadaan yang sedang terjadi secara alamiah. Konsep ini menekankan pentingnya sifat data yang diperoleh oleh penelitian kualitatif, yakni data alamiah. Data alamiah diperoleh dari hasil wawancara atau ungkapan langsung dari subjek peneliti dan dokumentasi ataupun catatan di lapangan. Data-data yang dikumpulkan dalam penelitian ini tidak dapat disajikan dalam bentuk angka, namun dapat dideskripsikan dalam bentuk bahasa. 


\section{Hasil dan Pembahasan}

\section{Tangibles (Bukti Fisik)}

Pola komunikasi diartikan sebagai bentuk atau pola hubungan dua orang atau lebih dalam proses pengiriman dan penerimaan pesan dengan tujuan pesan dapat dipahami bersama. Dalam program pembelajaran ini memakai pola Jaringan atau Pola Komunikasi All Channel adalah jaringan yang memiliki saluran terbuka yang memungkinkan setiap anggota dalam kelompok untuk berkomunikasi satu sama lain. Dinamika pola komunikasi ini adalah yang paling fleksibel di mana batas-batas posisi sudah tidak mempengaruhi jalannya komunikasi.(Robbins dan Judge, 2008:13).

Asrama Telkom University yang terletak dalam 1 (satu) kawasan Telkom University, yang dipisahkan antara asrama putra dan putri di jalan Telekomunikasi No. 1 Bandung Technoplex, Terusan Buah Batu, Bandung 40266. Pelayanan yang diberikan kepada mahasiswa baru Telkom University akan selalu dikaji setiap tahunnya dengan berkordinasi dengan pihak Telkom University agar selalu dapat meningkatkan mutu dan kualitas pelayanan agar para penghuni asrama akan selalu puas dengan pelayanan yang diberikan oleh asrama Telkom University.

Dalam memenuhi segala kebutuhan asrama untuk setiap mahasiswa baru Telkom University, maka ada beberapa fasilitas yang telah direncanakan oleh PT CSM. Fasilitas dan program kerja yang direncanakan ini tentu sudah dikordinasikan dengan pihak kampus dan telah mendapat persetujuan. Fasilitas yang telah direncanakan dapat peneliti uraikan dalam bentuk poin per poin sebagai berikut:

\section{Fasilitas Hunian}

a) Terdiri dari 8 (delapan) unit gedung untuk asrama putra dan 8 (delapan) unit gedung untuk asrama putri.

b) Masing-masing gedung asrama terdiri dari 4 (empat) lantai, dengan 94 unit kamar, masing-masing kamar seluas 23 meter persegi yang dilengkapi dengan 1 (satu) unit kamar mandi. 
c) Masing-masing kamar dilengkapi dengan 2 (dua) unit tempat tidur bertingkat untuk 4 (empat) orang penghuni.

d) Masing-masing penghuni mendapatkan 1 (satu) tempat tidur lengkap dengan kasur, bantal, guling, sprei, meja belajar, lemari pakaian, kursi belajar dan rak buku.

e) Masing-masing kamar dilengkapi dengan 1 (satu) tempat gantungan handuk, gantungan baju, cermin, ember besar, gayung air, tempat sampah, keset dan 1 (satu) buah dispenser (biaya penggunaan air galon menjadi tanggung jawab penghuni).

f) Setiap lantai gedung tersedia ruang lobby bersama dengan fasilitas televisi dan di lantai dasar tersedia 1 (satu) ruang sholat, televisi dan 1 (satu) dapur bersih.

\section{Fasilitas Pendukung Lainnya}

a) Akses point internet gratis tersedia dan apabila penghuni menginginkan akses internet dengan kecepatan (bandwith) tinggi dan yang lebih cepat, pihak pengelola asrama telah menyediakan fasilitas pulsa internet dengan sistem berbayar/ pulsa.

b) Tersedia tempat parkir khusus sepeda, dan pengelola menyediakan sepeda dengan jumlah terbatas yang dapat dipinjam secara bergantian.

c) Kantin dan laundry dengan sistem pembayaran menjadi tanggung jawab masing-masing penghuni. Lapangan futsal dan lapangan volly.

d) Sistem pengamanan dilakukan 24 jam baik didalam maupun di lingkungan asrama.

e) Tersedia poliklinik yang terletak dalam kawasan Telkom University dengan fasilitas mobil ambulance yang siap 24 jam.

f) Disetiap lantai dasar gedung asrama ditempat 1 (satu) orang petugas helpdesk dan tenaga cleaning service.Komunikasi Kelompok 


\section{Emphaty}

Adanya kemudahan dalam melakukan hubungan, komunikasi yang baik dan memahami kebutuhan mahasiswa penghuni asrama juga menjadi prioritas PT CSM dalam menjaga kualitas pelayanan di asrama putra maupun asrama putri. Agar tercipta kenyamanan dan keamanan hunian bagi para mahasiswa baru di asrama, Telkom University menempatkan Senior Residence, dimana ada mahasiswa senior di masingmasing gedung minimal 4 (empat) orang yang ditugaskan untuk membantu, membimbing, mengarahkan dan mengawasi kegiatan-kegiatan para mahasiswa penghuni di asrama.

Selain itu Telkom University juga menempatkan 1 orang petugas asrama di bagian lantai dasar masing-masing gedung yang selalu sigap dalam menangani segala keluhan dan masalah yang dialami oleh mahasiswa penghuni asrama. Baik senior residence maupun petugas asrama telah dibekali dengan training khusus agar mereka mengerti bagaimana caranya memperlakukan, menanggapi dan melayani keluhan mahasiswa dengan tetap ramah dan simpatik. Mereka juga dilatih untuk mampu mengingat penghuni asrama yang pernah melapor tentang permasalahan yang dihadapi, juga dilatih untuk tetap tenang dan sabar mendengarkan bermacam keluhan yang datang kepada mereka.

Tenaga cleaning service yang ditugaskan di kompleks asrama juga diwajibkan untuk melayani mahasiswa dengan baik dalam hal urusan kebersihan dan kerapihan asrama, khususnya ketika ada permintaan dari penghuni asrama untuk membersihkan kembali bagian-bagian ruangan asrama yang baru selesai digunakan mahasiswa untuk beraktivitas. Contohnya ketika dilaksanakan kegiatan soft skill seperti pelatihan, seminar atau workshop pada saat akhir pekan di bulan-bulan tertentu.

Tenaga medis yang bertugas di Poliklinik yang letaknya persis di seberang kompleks asrama juga dituntut untuk mampu mengenal setiap pasiennya yang mayoritas adalah mahasiswa dengan baik. Dokter poliklinik diharapkan juga mampu mengingat penyakit dan keluhan pasien sebelumnya, serta bersikap sabar serta menjadi pendengar yang baik ketika mahasiswa berkunjung untuk memeriksakan kesehatannya. 


\section{Reliability}

Kemampuan untuk membentuk atau menciptakan pelayanan yang akurat dan seperti yang dijanjikan telah dilakukan oleh PT CSM yang Dengan pembekalan dan briefing yang diberikan kepada para petugas asrama dan senior residence, diharapkan mereka mampu melakukan tugasnya dengan baik, dapat mengerti apa yang dibutuhkan oleh penghuni, kemudian menyelesaikan keluhan penghuni asrama, serta selalu bersedia membantu penghuni jika sewaktu-waktu menemui permasalahan terkait fasilitas, kebersihan dan keamanan asrama.

Selain itu Telkom University juga telah menyediakan layanan laundry untuk setiap penghuni asrama, dimana petugas laundry ini selalu datang sesuai jadwal dan tepat waktu untuk mengambil dan mengantarkan kembali pakaian para mahasiswa. Demikian juga dengan tenaga cleaning service yang ditugaskan di kompleks asrama dituntut untuk datang tepat waktu sesuai jadwal dan menyelesaikan pekerjaannya dengan rapi dan bersih sesuai standar yang ditetapkan oleh PT CSM.

Dokter poliklinik pun dituntut untuk mampu mendiagnosis penyakit pasien dengan akurat, karena jika memang keadaan pasien benar-benar darurat, dokter poliklinik harus cepat dan sigap dalam memberikan rujukan ke rumah sakit yang bekerjasama dengan Telkom University. Begitu juga dengan petugas security yang sudah dilatih khusus untuk selalu siaga terhadap segala bentuk antisipasi terkait dengan keamanan seluruh mahasiswa penghuni asrama, dimana mereka sudah harus paham betul bagaimana prosedur yang harus dilakukan ketika terjadi kemalingan, kerusuhan atau hal lain yang mengancam ketertiban lingkungan asrama.

\section{Responsiveness}

Kemauan untuk membantu mahasiswa dan menyediakan pelayanan yang cepat dilakukan oleh pihak pengelola asrama Telkom University telah memberikan sebuah buku keluhan di setiap helpdesk yang terdapat di setiap lobby gedung asrama dengan tujuan agar para penghuni dapat dengan mudah menyampaikan keluhannya kepada pihak 
pengelola asrama. Didalam website resmi asrama Telkom University (http://dormitory.telkomuniversity.ac.id) juga terdapat sebuah form keluhan agar para penghuni asrama dapat langsung menyampaikan keluhannya kepada pihak pengelola asrama. Dari penyediaan layanan buku keluhan dan form keluhan di website ini, diharapkan segala keluhan dan masalah yang dihadapi mahasiswa penghuni asrama dapat segera direspon dan tersolusikan dengan cepat.

Dalam rangka mencapai tujuan terbentuknya mahasiswa yang tangguh dan disiplin, yang memiliki kepribadian dan berkemampuan bekerja berlandaskan intelektual, berjiwa nasionalis Indonesia, iman dan taqwa, maka penghuni asrama diberikan kegiatan-kegiatan softskill yang dilaksanakan oleh unit khusus di Telkom University dalam bentuk seminar atau pelatihan-pelatihan yang dilaksanakan selama masa waktu tinggal di asrama. Dalam beberapa kesempatan, kegiatan tersebut juga dapat dilakukan berbentuk permainan maupun kegiatan hari sehat, lingkungan bersih yang dilaksanakan pada akhir pekan pada bulan-bulan tertentu. Tentunya Tim Pembina kegiatan softskill ini diharapkan mampu memfasilitasi pengagendaan kegiatan-kegiatan selanjutnya sesuai kebutuhan dan aspirasi mahasiswa penghuni asrama.

\section{Assurance}

PT CSM selaku pengelola asrama mahasiswa Telkom University memberikan jaminanjaminan yang dijanjikan agar selalu sesuai dengan kenyataan. Contohnya, terkait dengan permasalahan fasilitas kamar:

a. Masing-masing penghuni (mahasiswa) mendapatkan 1 (satu) tempat tidur lengkap dengan kasur, bantal, guling, sprei, meja belajar, lemari pakaian, kursi belajar dan rak buku.

b. Masing-masing kamar dilengkapi dengan 1 (satu) tempat gantungan handuk, gantungan baju, cermin, ember besar, gayung air, tempat sampah, keset dan 1 (satu) buah dispenser 
Agar tercipta kenyamanan dan keamanan hunian bagi para mahasiswa baru di asrama, Telkom University menempatkan Senior Residence, dimana ada mahasiswa senior di masing-masing gedung minimal 4 (empat) orang yang ditugaskan untuk membantu, membimbing, mengarahkan dan mengawasi kegiatan-kegiatan para mahasiswa penghuni di asrama.

Terkait dengan masalah jaminan keamanan mahasiswa penghuni asrama, PT CSM menegaskan bahwa sistem pengamanan dilakukan 24 jam baik di dalam maupun di lingkungan asrama Telkom University, dimana selalu ada minimal 2 orang security terlatih yang berjaga dengan sistem shift di setiap kompleks asrama putra dan asrama putri. Khusus untuk asrama putri, security yang bertugas juga wanita untuk menjamin kenyamanan mahasiswi, terutama bagi mereka yang berhijab.

Terkait dengan jaminan kesehatan mahasiswa penghuni asrama, Telkom University juga telah menyediakan poliklinik yang terletak dalam kawasan Telkom University dengan fasilitas mobil ambulance yang siap diakses 24 jam apabila terjadi keadaan darurat. Dokter yang dipilih untuk bertugas di poliklinik pun merupakan dokter berpengalaman dan mempunyai ijin praktik, buka dokter muda (ko-as) yang pengalaman lapangannya masih sedikit.

\section{Simpulan}

Sebagai wujud komitmen memberikan kepuasan kepada konsumennya (mahasiswa), Telkom University menyediakan berbagai fasilitas yang menunjang proses belajar mengajar dan kegiatan yang berkaitan dengan kegiatan mahasiswa seperti pengadaan asrama untuk mahasiswa baru dengan pertimbangan kemudahan dalam mobilitas, biaya yang jauh lebih murah dan lokasi yang lebih strategis karena lokasinya sangat dekat dengan kampus. Dari aspek tangibles (bukti fisik), di dalam asrama disediakan fasilitas yang bisa digunakan langsung oleh penghuni, diantaranya kamar lengkap beserta isinya, wifi, laundry, televisi, sarana olahraga, keamanan, poliklinik dan sebagainya. Dari aspek 
emphaty, kemudahan dalam melakukan hubungan, komunikasi yang baik dan memahami para mahasiswa penghuni asrama diterapkan melalui keberadaan senior residence, petugas jaga asrama, tenaga cleaning service, dan tenaga medis di poloklinik. Dari aspek reliability, kemampuan memberikan pelayanan yang dijanjikan dengan segera dan memuaskan, diterapkan melalui penugasan senior residence, petugas jaga asrama, tenaga cleaning service, tenaga medis di poloklinik, dan petugas security yang sudah terlatih dan berpengalaman. Dari aspek responsiveness, sikap tanggap dalam memberikan pelayanan yang dibutuhkan dan dapat menyelesaikan dengan cepat dilakukan dengan pengadaan helpdesk di setiap blok dan form keluhan melalui website. Dari aspek assurance, yang merupakan jaminan yang dijanjikan sesuai dengan kenyataan, berupa fasilitas kamar, senior residence, petugas jaga asrama, fasilitas kemanan dan ambulance 24 jam.

\section{Daftar Pustaka}

Tjiptono, Fandy. 2012. Service Management Mewujudkan Layanan Prima. Yogyakarta: Andi Offset.

Putra, Rico Anugrah. 2016. Pengaruh Kualitas Pelayanan Asrama Telkom University Terhadap Kepuasan Mahasiswa Penghuni Asrama Angkatan 2015/2016. Bandung: Perpustakaan Telkom University.

Tjiptono, Fandy. (2008). Strategi Pemasaran, Edisi 3, Yogyakarta: Andi Offset.

Kotler, Philip \& Keller, Kevin Lane. (2009). Manajemen Pemasaran, Jilid 1, Edisi 13, Penerbit Erlangga, Jakarta.

Kotler, Philip \& Armstrong, Gary. (2012). Prinsip-Prinsip Pemasaran. Edisi 13. Jilid 1. Jakarta: Erlangga

Wijaya, Tony. (2011). Manajemen Kualitas Jasa. Jakarta : PT. INDEKS 